\title{
First report of Tomato chlorotic spot virus on Mirabilis jalapa
}

\author{
L. M. L. Duarte ${ }^{1}$ A. L. R. Chaves ${ }^{1}$ - E. W. Kitajima ${ }^{2}$ L. K. Rodrigues ${ }^{1}$. \\ R. Harakava ${ }^{3}$ - M. A. V. Alexandre ${ }^{1}$
}

Received: 25 September 2015 / Accepted: 14 March 2016 / Published online: 29 March 2016

(C) Australasian Plant Pathology Society Inc. 2016

\begin{abstract}
Mosaic symptoms in Mirabilis jalapa plants from a public garden in the city of São Paulo, Brazil, were associated with the presence of Tomato chlorotic spot virus (TCSV-Mir-BR07). TCSV-Mir-BR07 was mechanically transmitted to healthy $M$. jalapa plants. Phylogenetic analysis revealed a monophyletic group formed by South American TCSV isolates separate to those from Central and North America. This is the first report of natural TCSV infection in M. jalapa.
\end{abstract}

Keywords Tospovirus $\cdot$ Bunyaviridae $\cdot$ Four-o'clock plant . RT-PCR · Phylogeny

Mirabilis jalapa (Nyctaginaceae), also known as the fouro'clock plant, is an ornamental flowering plant from Peru widely used in public and private gardens in Brazil for the beauty of its flowers (Souza and Lorenzi 2012). Moreover,

L. M. L. Duarte

duarte@biologico.sp.gov.br

1 Laboratório de Fitovirologia Fisiopatologica, Instituto Biológico, Av. Conselheiro Rodrigues Alves, 1252, CEP 040140-002, São Paulo, SP, Brazil

2 Escola Superior de Agricultura Luiz de Queiróz, USP, CP 09, CEP 13418-900, Piracicaba, SP, Brazil

3 Laboratório de Bioquímica Fitopatologica, Biológico, Av. Conselheiro Rodrigues Alves, 1252, CEP, 040140-002, São Paulo, SP, Brazil it is easy to grow from seeds, cuttings and tubers. $M$. jalapa also has medicinal uses, since it contains several active compounds extracted from different organs, including ribosome-inactivating protein (RIP) associated with anti-viral activity, antifungal phenolic compounds, antimicrobial peptides, and natural antioxidant and antimicrobial agents (Hajji et al. 2010).

Only a few natural viral infections of $M$. jalapa have been reported: Parietaria mottle virus (Ilarvirus) in Italy, Mirabilis jalapa mottle virus (Carlavirus) in the USA and Basella rugose mosaic virus (Potyvirus) in China (Parrella 2002; Hatlestad et al. 2011; Wang et al. 2012). A new species of Caulimovirus named Mirabilis mosaic virus was also described in the United States (Brunt and Kitajima 1973); however, the host was Mirabilis nyctaginea, a synonym for Oxybaphus nyctagineus. In Brazil, M. jalapa has not been described as a natural virus host.

In a survey aimed at detecting viruses in urban ornamental species in the city of São Paulo, Brazil, a garden containing M. jalapa plants exhibiting systemic foliar mosaic (Fig. 1) attracted our attention. In order to identify the causal agent, electron microscopy, experimental transmission studies to other host species, RT-PCR and sequencing were carried out.

Several quasi-spherical particles approximately $100 \mathrm{~nm}$ in diameter were observed in naturally infected, negatively stained $M$. jalapa leaf extract. In thin sections of the leaf lesions, membrane-bounded particles about the same size of those found in extracts, were found in the lumen of the endoplasmic reticulum (Fig. 2) suggesting that these $M$. jalapa plants were infected with a tospovirus. 


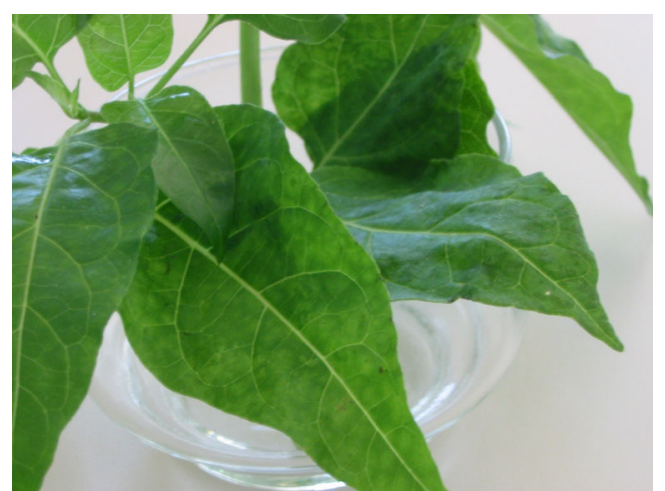

Fig. 1 Mosaic symptoms on naturally infected Mirabilis jalapa leaves

Host plants, including M. jalapa, were grown from seeds and kept in insect-proof greenhouses. The sanitary status of $M$. jalapa plants was verified by electron microscope observations. Six plants of each species (Chenopodium amaranticolor, Gomphrena globosa (Amaranthaceae), Datura stramonium and Nicotiana benthamiana (Solanaceae) and twenty healthy M. jalapa plants were mechanically inoculated with $M$. jalapa infected leaf. One plant of each species was

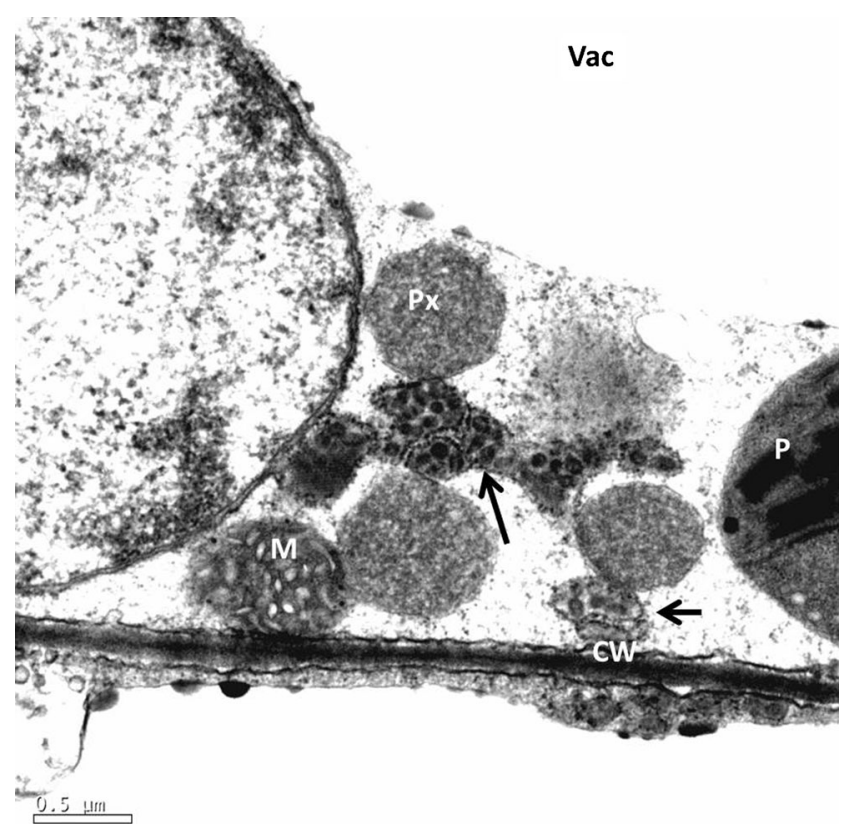

Fig. 2 In situ transmission electron micrograph of isolate of Tomato chlorotic spot virus, in a leaf parenchymal cell of a naturally infected Mirabilis jalapa plant. Presumed virions, as judged by morphology, within cisternae of the endoplasmic reticulum (arrows). $C W$ cell wall, $M$ mitochondrion, $P$ chloroplast, $P x$ peroxisome, $V a c$ vacuole rubbed with inoculation buffer as control. The virus was not transmitted from the donor plant to other hosts, likely due to the presence of potent virus-inhibiting substances common in Caryophyllales species (Chessin 1983). On the other hand, it was transmitted to five of the healthy $M$. jalapa plants, but with more severe symptoms than those seen in the donor plant, including leaf and stem necrosis (Fig. 3). Inoculated plants were kept in a greenhouse at an average temperature of around $30{ }^{\circ} \mathrm{C}$, which could explain the severity of symptoms. According to Llamas-Llamas et al. (1998), a day/night temperature regime of $29 / 24{ }^{\circ} \mathrm{C}$ favoured infection by the tospovirus Tomato spotted wilt virus (TSWV) in D. stramonium, N. tabacum and Physalis ixocarpa and resulted in more severe symptoms.

Total RNA from natural and experimentally infected four-o'clock plants was extracted using Trizol LS reagent, according to the manufacturer's instructions (Gibco BRL, USA), precipitated with ethanol and used as a template in RT-PCR with BR60 and UNIV1 primers (Mumford et al. 1996). A ca. 800 bp fragment corresponding to part of the conserved region of Tospovirus S RNA was amplified and sequenced using forward and reverse primers, with three replications. After trimming low quality bases at the 5' and $3^{\prime}$ ends of the sequenced PCR product, a $678 \mathrm{bp}$ sequence obtained from naturally infected four-o'clock plant was compared to those deposited in GenBank. BlastN analysis confirmed that the sequence of $M$. jalapa tospovirus was similar to Tomato chlorotic spot virus (TCSV). The highest nucleotide and amino acid identities were recorded in the TCSV sequences isolated from vegetable and ornamental plants from different geographic regions (Table 1).

Maximum likelihood (ML) analyses (PAUP v. 4.0b10 for Macintosh) were performed using the stardecomposition algorithm and tree bisection and reconnection (TBR) branch-swapping algorithm after estimation of nucleotide substitution and gamma distribution (Modeltest v.3.06). Nucleotide sequences corresponded to the nucleocapsid gene available in GenBank for: i) the Tospovirus species, and ii) TCSV isolates. Bootstrap values were calculated using the branch-and-bound method after resampling (1000 replicates). Our results confirmed the findings of Torres et al. (2012), who reported the occurrence of a group of American tospoviruses, based on the formation of a monophyletic group by American Tospovirus species, substantiated by a high bootstrap value. $M$. jalapa tospovirus formed a sister group with TCSV, with a $95 \%$ bootstrap value (Fig. 4a). 
Fig. 3 Experimentally infected Mirabilis jalapa. a Plant showing severe mosaic, leaf deformation, chlorotic and necrotic spot symptoms. b Plant showing necrotic lesions on the stem
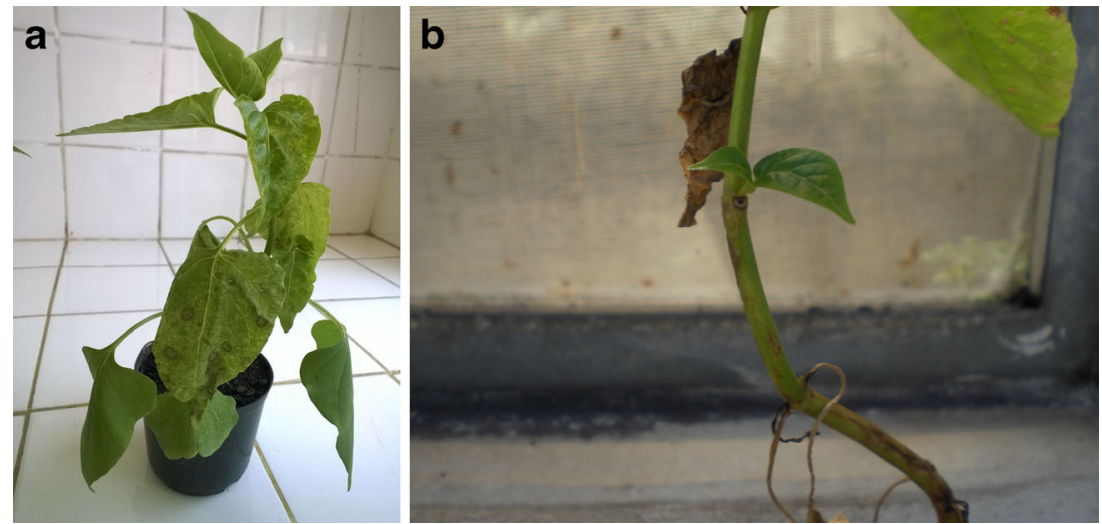

Phylogenetic analysis of TCSV isolates showed a tendency for clustering according to the geographic region (Fig. 4b). South American isolates formed a separate monophyletic group to those from Central and North America. Webster et al. (2015) reported that the RNAs of TCSV isolates from Florida (USA), Puerto Rico, and the Dominican Republic all share high levels of nucleotide identity with the corresponding RNAs of TCSV

Table 1 Nucleotide (nt) and amino acid (aa) sequence identities (\%) in Tomato chlorotic spot virus isolated from Mirabilis jalapa (KP276236) as well as different hosts and geographic regions

\begin{tabular}{lll}
\hline GenBank number & nt & aa \\
\hline AF282982 (BR) & 99.0 & 100 \\
KJ399303 (DR) & 98.5 & 98.8 \\
JX244198 (USA) & 97.7 & 97.7 \\
JX 244196 (USA) & 98.5 & 98.8 \\
S54325 (BR) & 93.8 & 91.9 \\
AF521102 (BR) & 98.8 & 100 \\
AF413110 (BR) & 93.4 & 90.7 \\
KP172480 (USA) & 98.1 & 98.8 \\
KJ399304 (DR) & 98.5 & 98.8 \\
HQ634666 (SA) & 98.1 & 98.8 \\
KM610235 (USA) & 97.3 & 96.5 \\
AM887766 (BR) & 98.1 & 100 \\
AY380813 (BR) & 98.1 & 98.8 \\
AF521103 (BR) & 98.5 & 100 \\
U49709 (AR) & 96.1 & 97.7 \\
JQ034525 (BR) & 96.1 & 98.8 \\
AF454913 (BR) & 98.5 & 100 \\
\hline
\end{tabular}

$\mathrm{AR}=$ Argentina, $\mathrm{BR}=$ Brazil, $\mathrm{DR}=$ Dominican Republic, $\mathrm{SA}=$ South Africa, USA = United States of America isolates from South America. With regard to Brazilian TCSV, the isolate from M. jalapa (TCSV-Mir-BR07, GenBank number KP276236) formed a monophyletic group with isolates from the states of Rio Grande do Sul (JQ034525) and Minas Gerais (AF282982), as well as Argentina (U49709), in the maximum-likelihood tree. The isolate from P. peruviana clustered with Argentinean isolates, corroborating the findings of Eiras et al. (2012). It is important to note that Rio Grande do Sul borders Argentina, possibly facilitating the spread of TCSV, and that the virus is highly prevalent in the border region between Brazil and Argentina (Williams et al. 2001).

Recombination analysis for sequences of TCSV isolates $(P$-value $=0.05)$ conducted using RDP3 software (Martin et al. 2010) was inconclusive because it was not substantiated by at least four of the seven methods implemented in RDP. Furthermore, there are few complete sequences of the TCSV $\mathrm{N}$ gene in GenBank, hampering greater robustness of the analysis.

Although tospoviruses can be mechanically transmitted under experimental conditions, their dispersal and survival in nature depends on transmission to plants via thrips vectors (Rotenberg et al. 2015). Approximately 520 thrips species (Thysanoptera) from 139 genera and six families are known in Brazil, with the Terebrantia suborder being the major Tospovirus vector species in tropical and subtropical regions (Monteiro 2002). However, there are no reports in the literature of thrips in M. jalapa in Brazil.

To date, there is no record of natural tospovirus infection in M. jalapa. However, studies conducted in Mexico and Japan found that M. jalapa was an experimental host for TSWV (Martinez et al. 1999). On the other hand, it was not experimentally infected by INSV (Okuda et al. 2010). It is noteworthy that neither natural 
a

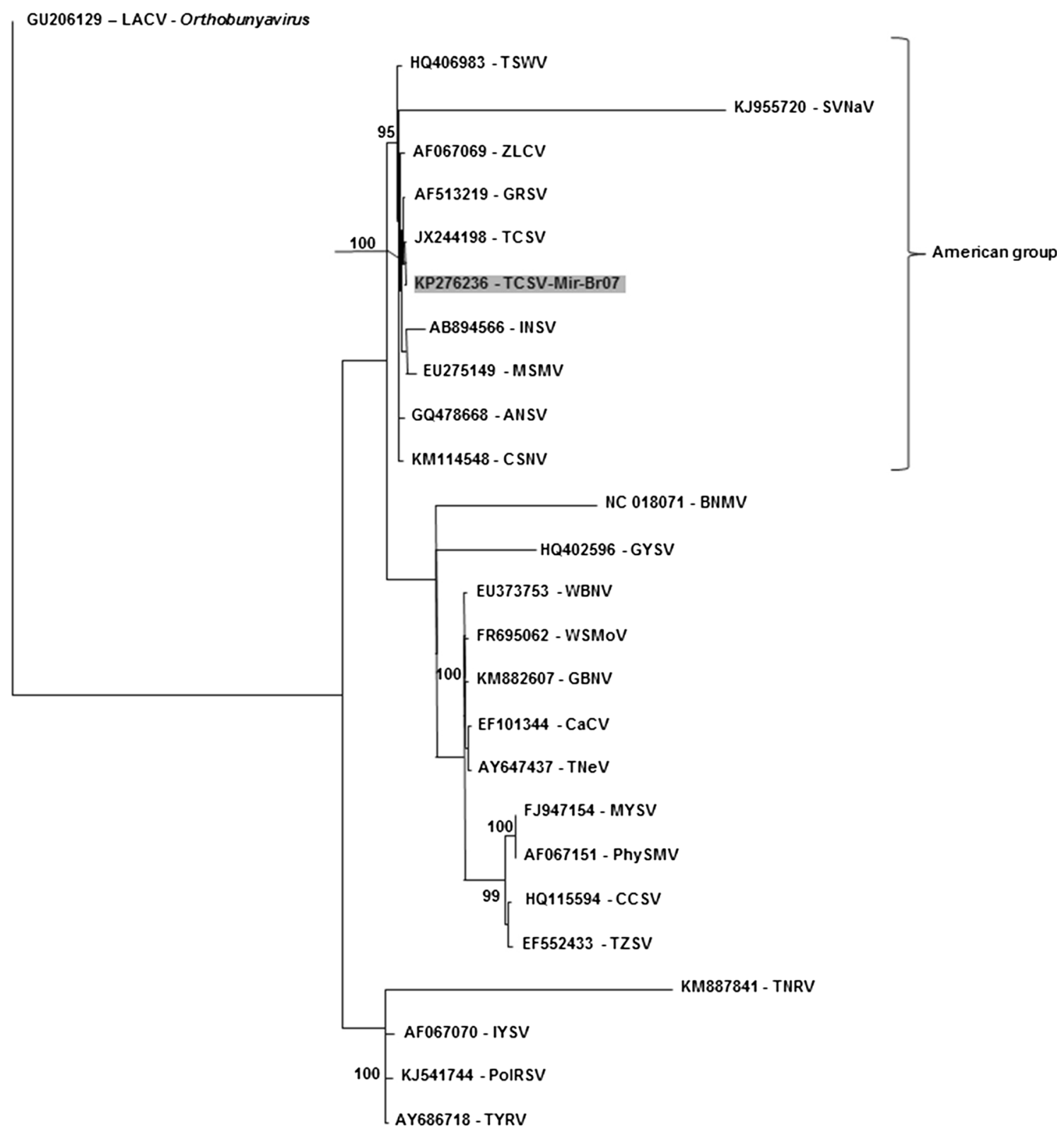

1

Fig. 4 A maximum likelihood tree constructed using nucleocapsid (N) partial sequences available in GenBank for (a) The Tospovirus species, with the La Crosse virus (LACV - Orthobunyavirus) as outgroup ( $\operatorname{TrN}$ nucleotide substitution model $+\mathrm{I}+\mathrm{G}, \mathrm{I}=0.0107, \mathrm{G}=1.1360$ ). (b) The Tomato chlorotic spot virus (TCSV) isolates from different hosts and geographic regions, with the Tomato spotted wilt virus (TSWV) as outgroup (HKY nucleotide substitution model). ANSV Alstroemeria necrotic streak virus, $B N M V$ Bean necrotic mosaic virus, $\mathrm{CaCV}$ Capsicum chlorosis virus, $C C S V$ Calla lily chlorotic spot virus, $C S N V$ Chrysanthemum stem necrosis virus, GBNV Groundnut bud necrosis

nor experimental infections by TCSV in $M$. jalapa have been reported. virus, GRSV Groundnut ringspot virus, GYSV Groundnut yellow spot virus, INSV Impatiens necrotic spot virus, IYSV Iris yellow spot virus, $M S M V$ Melon severe mosaic virus, MYSV Melon yellow spot virus, PhySMV Physalis severe mottle virus, PolRSV Polygonum ringspot virus, $S V N a V$ Soybean vein necrosisassociated virus, $T N e V$ Tomato necrosis virus, TNRV Tomato necrotic ringspot virus, TZSV Tomato zonate spot virus, TYRV Tomato yellow ring virus, $Z L C V$ Zucchini lethal chlorosis virus, $W B N V$ Watermelon bud necrosis virus, WSMoV Watermelon silver mottle virus. Bootstrap values are indicated near the branches

Although $M$. jalapa plants are also propagated by seeds and TCSV cannot be transmitted in this manner, 


\section{b}

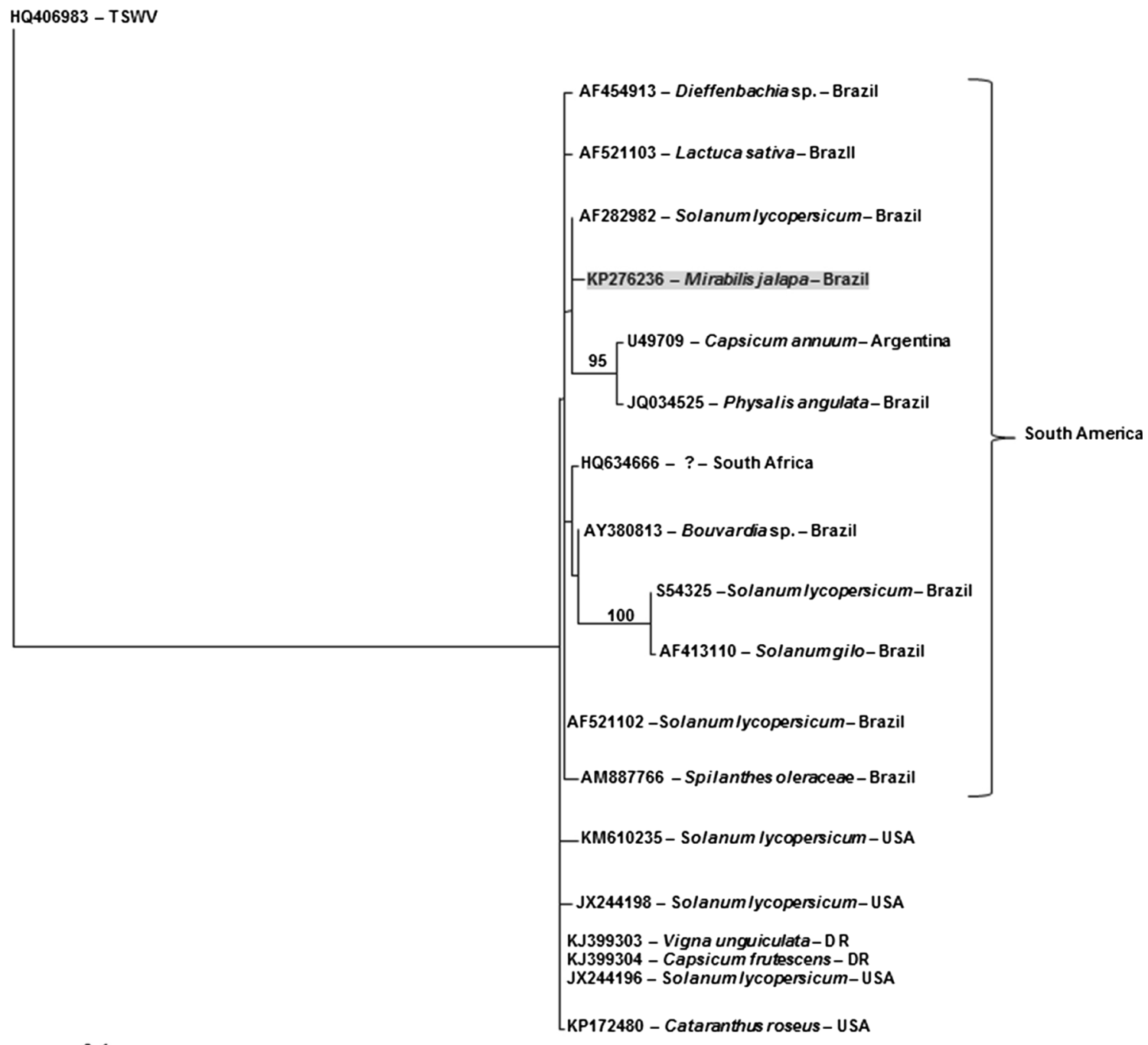

Fig. 4 (continued)

TCSV-infected plants were detected in a public garden in São Paulo, Brazil, suggesting an accidental infection. Thrips may have acquired the virus on colonizing another infected species and transmitted it to the fouro'clock plants. This is the first report of natural TCSV infection in M. jalapa.

\section{References}

Brunt AA, Kitajima EW (1973) Intracelular location and some properties of Mirabilis mosaic virus, a new member of the Cauliflower mosaic group of viruses. Phytopath Z 76:265-275

Chessin M (1983) Is there a plant interferon? Botanic Rev 49:1-28

Eiras M, Costa IFD, Chaves ALR, Colariccio A, Harakava R, Tanaka FAO, Garcêz RM, Silva LA (2012) First report of a tospovirus in a commercial crop of Cape gooseberry in Brazil. New Dis Rep 25:25
Hajji M, Jarraya R, Lassoued I, Masmoudi O, Damak M, Nasri M (2010) GC/MS and LC/MS analysis, and antioxidant and antimicrobial activities of various solvent extracts from Mirabilis jalapa tubers. Process Biochem 45:1486-1493

Hatlestad GJ, Elam L, Gonzalez A, Lloyd AM (2011) Mirabilis jalapa mottle virus: a new carlavirus infecting four o'clock. Arch Virol 156: 2109-2111

Llamas-Llamas ME, Zavaleta-Mejia B, Gonzalez-Hernandez VA, Cervantes-Diaz L, Santizo-Rincon JA, Ochoa-Martinez DL (1998) Effect of temperature on symptom expression and accumulation of tomato spotted wilt virus in different host species. Plant Pathol 47: 341-347

Martin DP, Lemey P, Lott M, Moulton V, Posada D, Lefeuvre P (2010) RDP 3: a flexible and fast computer program for analyzing recombination. Bioinformatics 26:2462-2463

Martinez DLO, Zavaleta-Mejía E, Mora-Aguilera G, Johansen RM (1999) Implications of weed composition and thrips species for the epidemiology of Tomato spotted wilt virus in chrysanthemum (Dendranthema grandiflora). Plant Pathol 48: $707-717$ 
Monteiro CM (2002) The Thysanoptera fauna of Brazil. In: Marullo R, Mound LA (eds) Thrips and tospovirus: proceedings of the 7th International Symposium on Thysanoptera. Australian National Insect Collection, Canberra, pp 325-340

Mumford RA, Barker I, Wood KR (1996) An improved method for detection of Tospoviruses using the polymerase chain reaction. $\mathrm{J}$ Virol Meth 57:109-115

Okuda M, Fuji S, Okuda O, Sako K, Iwanami T (2010) Evaluation of the potential of thirty-two weed species an infection sources of Impatiens necrotic spot virus. J Plant Pathol 92(4):357-361

Parrella G (2002) First report of Parietaria mottle virus in Mirabilis jalapa. Plant Pathol 51(3):401

Rotenberg D, Jacobson AL, Schneweis AN, Whitfield AE (2015) Thrips transmission of tospoviruses. Curr Opin Virol 15:80-89

Souza VC, Lorenzi H (2012) Botânica sistemática. Instituto Plantarum, Nova Odessa
Torres R, Larenas J, Fribourg C, Romero J (2012) Pepper necrotic spot virus, a new tospovirus infecting solanaceous crops in Peru. Arch Virol 157:609-615

Wang JG, Peng JJ, Chen HR, Chen SY (2012) First report of Basella rugose mosaic virus infecting four o'clock (Mirabilis jalapa) in China. Plant Dis 96:294

Webster CG, Frantz G, Reitz SR, Funderburk JE, Mellinger HC, McAvoy E, Turechek WW, Marshall SH, Tantiwanich Y, McGrath MT, Daughtrey ML, Adkins S (2015) Emergence of Groundnut ringspot virus and Tomato chlorotic spot virus in vegetables in Florida and the southeastern United States. Phytopathology 105:388-398

Williams LV, López Lambertini PM, Shohara K, Biderbost EB (2001) Occurrence and geographical distribution of tospovirus species infecting tomato crops in Argentina. Plant Dis 85:1227-1229 